\title{
SISTEM AMONG KI HAJAR DEWANTARA DALAM ERA REVOLUSI INDUSTRI 4.0
}

\author{
Nelly Indrayani \\ Email : nellyindrayani91@gmail.com
}

\begin{abstract}
Abstrak
Revolusi Industri 4.0 ditandai dengan penggunaan komputer dengan sistem jaringan internet. Kemajuan ini memberikan kemudahan dalam segala aspek kehidupan manusia. Terkait dalam dunia pendidikan revolusi industri 4.0 dalam sistem pembelajarannya memberikan dampak baik kepada pengajar maupun kepada anak didik. Tenaga pengajar perlu memberikan metode, model, dan strategi pembelajaran yang relevan dengan kemajuan revolusi indsutri 4.0, sedangkan anak didik mesti melek dan bijak dalam pemanfaatan kemajuan ilmu pengetahuan dan teknologi untuk kepentingan pembelajaran. Pendekatan pendidikan sistem among KI Hajar Dewantara antara peserta didik dan guru dalam era globalisasi perlu ditumbuhkembangkan pada era masa kini. Pada praktiknya peserta didik dalam pemanfaatan teknologi seringkali terlihat, pertama sikap kurang acuh dan tidak bijak dalam pemanfaat penggunaan teknologi di kelas. Kedua, khususnya penggunaan handphone ditemukan dalam proses pembelajaran sejarah bersifat tesktual. Peserta didik tidak memperlihatkan analisa pemahaman dan perluasan wawasan secara kontekstual. Akibatnya penggunaan teknologi khususnya handphone dalam proses pembelajaran tidak mencapai sasaran. Bahkan pemaanfaatn teknologi membuat mahasiswa belajar sistem kebut semalam dalam menyelesaikan berbagai tugas keilmuan dilingkungan akademik. Kondisi ini perlu melihat kembali sistem pembelajaran yang dicanangkan oleh KI Hajar Dewantara yang dikenal sistem among. Sistem among menurut KI Hajar Dewantara menekankan pada manusia yang memiliki cipta (Kognitif), rasa (Afektif) dan karsa (Konatif). Pengembangan manusia seutuhnya menuntut pengembangan semua secara seimbang. Penelitian ini termasuk penelitian kepustakaan (library research). studi pustaka (Library Research) adalah jenis penelitian yang pengumpulan datanya dilakukan dengan cara menghimpun data-data dari berbagai literatur baik berupa buku maupun sumber-sumber tertulis lainya. Penulis menggunakan teknik analisis data yakni konten analisis.
\end{abstract}

Kata Kunci: Sistem among, Ki Hajar Dewantara, Era Revolusi Industri 4.0

\section{Pendahuluan}

Perkembangan ilmu pengetahuan dan teknologi berbasis internet menjadikan segala aktivitas berjalan lancar dan cepat dalam semua lini kehidupan. Mulai dari akitivitas kehidupan rumah tangga, hingga dunia akademik. Era ini akan mendisrupsi berbagai aktivitas manusia dalam berbagai bidang. Baik bidang ekonomi, sosial, politik maupun pendidikan. Terlihat ketika jasa transportasi telah menyediakan kehadiran taksi dan ojek daring. Transaksi jual beli yang dapat dilakukan pemesanan online, pemuatan berita yang tidak hanya didapatkan melalui media 
cetak, dan telah disajikan dalam bentuk online. Selanjutnya revolusi industri 4.0 juga memberikan perubahan dalam interaksi sosial tanpa batas. Bidang pendidikan tak kalah penting juga telah dapat menggunakan media pembelajaran berbasis internet.

Kemajuan teknologi memang telah mempermudah kehidupan manusia. Sejak penemuan mesin dan dimulainya era otomatisasi telah membuat produksi semakin berlipat dan memangkas waktu serta biaya yang dikeluarkan. Pada akhirnya berbagai kemudahan ini berdampak besar terhadap manusia, karena membuat penggunaan tenaga manusia berkurang secara signifikan. Akibatnya, terjadi peningkatan jumlah pengangguran. Pada tahap ini perlu adanya paradigma pembangunan yang tidak saja meningkatkan kemampuan manusia di bidang teknologi saja, namun juga perlu meningkatkan mentalitas manusianya sendiri. (Banu Prasety, dkk, Tth : 25).

Mentalitas manusia salah satunya dibangun melalui pendidikan. Lembaga pendidikan harus mampu menjawab tantangan tersebut dengan merubah arah dan orientasi pendidikan untuk menghgasilkan manusia yang unggul. Berdasarkan UU RI Nomor 20 Tahun 2003 tentang Sisdiknas Bab II Pasal (3) disebutkan bahwa pendidikan nasional berfungsi mengembangkan kemampuan dan membentuk watak serta peradaban bangsa yang bermartabat dalam rangka mencerdaskan kehidupan bangsa, bertujuan untuk berkembangnya potensi peserta didik agar manusia yang beriman dan bertakwa kepada Tuhan Yang Maha Esa, berakhlak mulia, sehat, berilmu, cakap, kreatif, mandiri, dan menjadi warga negara yang demokratis serta bertanggung jawab (Afnil Guza, 2009 : 5). Tujuan itu dikatakan bahwa manusia sebagai manusia berjati diri bangsa Indonesia (Hendra Suwardana, 2017 : 106)

Kajian empiris menunjukkan bahwa sistem pengelolaan pendidikan di Indonesia masih banyak menggunakan cara konvensional. Pembelajaran yang sering kali dilakukan satu arah dan terpusat pada pendidik. Kemudian lebih menekankan pengembangan kecerdasan dalam arti sempit dan kurang memberi perhatian kepada pengembangan bakat kreatif peserta didik. Padahal kreativitas di samping bermanfaat untuk pengembangan diri anak didik juga merupakan kebutuhan akan perwujudan diri sebagai salah satu kebutuhan paling tinggi bagi manusia (Rusniati, 2015). Ternyata pendidikan sampai sekarang ini hanya menekankan pada pengembangan daya cipta, dan kurang memperhatikan pengembangan olah rasa dan karsa. Jika berlanjut terus akan menjadikan manusia kurang humanis atau manusiawi (Br. Theo Riyanto, 
2004). Hal ini tentu berbanding terbalik dengan sistem pendidikan KI Hajar Dewantara yang menekankan kepada pengembangan daya cipta rasa dan karsa.

Pada perkembangannya sistem pembelajaran yang berlangsung sebenarnya telah banyak memiliki metode, model dan media pembelajaran bervariasi berbasis internet. Hal ini tentu saja ditujukan untuk peningkatan keberhasilan peserta didik dalam pembelajaran sejarah. Apalagi pembelajaran sejarah yang berkutat pada banyak teks, maka sistem pembelajaran berbasis internet sangat tepat dilakukan pada era revolusi industri 4.0.

Berdasarkan observasi dalam pertemuan tatap muka di kelas, kemajauan ilmu pengetahuan dan teknologi, khususnya dalam penggunaan handpone yang mestinya memberikan kemudahan bagi mahasiswa dalam menambah pemahaman pembelajaran sejarah. Mahasiswa yang semestinya mendapatkan pengetahuan, wawasan dan pemahaman yang baik tentang sejarah, serta kemampuan melakukan analisa yang kuat dalam mempelajari masa lampau dan mengaitkan dengan persoalan hari ini. Pada kenyataannya ketersediaan kemajuan teknologi khususnya dalam penggunaan handpone saat di kelas, dalam diskusi sejarah terlihat kaku dan monoton. Artinya materi teks sejarah yang mereka dapatkan secara online melalui smartphone cedrung tekstual. Akibatnya tingkat analisa dan pemahaman mereka juga rendah, dan tidak diikuti analisa secara kontekstual.

Kemajuan teknologi revolusi industri 4.0 telah memberikan kesempatan akses yang sangat luas tentang materi diskusi, seharusnya peserta didik cukup kaya dengan referensi jika penggunaan media pembelajaran berbasis internet dapat dilakukan sebaik-baiknya. Harapannya dapat meningkatan kemampuan analisa dan perluasan wawasan mereka, sehingga diskusi berlangsung cukup intens dan alot. Akan tetapi pada pratiknya di kelas mahasiswa penggunaan teknologi khususnya handphone hanya terbatas membacakan materi yang diakses melalui internet tanpa ada analisa dan pemahaman yang baik.

Berdasarkan uraian di atas, tantangan untuk kemjuan teknologi revolusi industri perlu dipersiapkan melalui pendidikan. Pendidikan sistem among KI Hajar Dewantara melalui tulisan ini penulis ingin melihat sangat relevan dengan kemajuan ilmu pengetahuan dan teknologi. Sistem among merupakan sistem pendidikan yang bertujuan untuk menghasilkan manusia yang dapat mengatur dirinya sendiri, manusia yang berdiri sendiri dalam merasa, berpikir, dan 
bertindak, manusia yang berkepribadian dan berkarakter (le Febre, 1952:12-13). Pada tahap ini pendidikan sistem among KI Hajar Dewantara memliki daya cipta, rasa, dan karsa. Pengembangan manusia seutuhnya menuntut pengembangan semua daya secara seimbang (Br. Theo Riyanto, 2004) dalam kaitannya revolusi industry 4.0.

Berdasarkan masalah dalam uraian di atas dapat dirumusakan dalam bentuk pertanyaa yakni bagaimana sistem among KI Hajar Dewantara dalam era revolusi industry 4.0.

\section{Pembahasan}

\section{Riwayat K.I Hajar Dewantara}

Ki Hadjar Dewantara lahir dengan nama Soewardi Suryaningrat pada hari kamis Legi, tanggal 2 puasa 1818 atau 2 mei 1889. Beliau merupakan anggota keluarga keraton Pura Pakualam Yogyakarta, Istana atau kadipaten Paku Alaman merupakan salah satu kerajaan dari empat kerajaan di Jawa tengah (Soeratman, 1989 : 10). Ki Hadjar Dewantara merupakan cucu dari Sri Paku Alam III, ayahnya bernama Kanjeng Pangeran Haryo Suryaningrat yang merupakan putra Kanjeng Gusti Hadipati Haryo Suryosasraningrat yang bergelar Sri Paku Alam III, dan ibundanya bernama Raden Ayu Sandiyah. Ki Hadjar Dewantara merupakan anak ke lima dari sembilan bersaudara (Rahardjo, 2018 : 9)

Soewardi Suryaningrat merupakan keturunan bangsawan yang juga keturunan ulama, sebab beliau adalah keturunan dari sunan kalijaga. Sebagaimana seorang keturunan bangsawan dan ulama, Soewardi Suryaningrat Dididik dan dibesarkan dalam lingkungan sosio kultural dan religius. Suasana religius dilingkungan keluarganya yang dibuktikan dengan adanya langgar dan masjid disekitar rumahnya yang dapat mempertebal agamanya. Setiap hari jum'at beliau melaksanakan sholat di mesjid bersama para ulama. Soewardi juga banyak menerima ajaran agama Islam dari ayahnya yaitu pangeran Suryaningrat. Selain ajaran islam, Suwardi juga mendapat pelajaran berupa ajaran lama yang dipengaruhi oleh filsafat Hindu yang terserat dalam ceritera wayang. Pelajaran tentang seni sastra, gending, dan seni suara diberikan secara mendalam (Darsiti Soeratman, : 15-16)

Suwardi suryaningrat pernah mendapatkan pendidikan agama di pesantren Kalasan di bawah asuhan K.H. Abdurrahman. Pendidikan dasar Soewardi di tempuh di ELS Europesche Lagere School yang awalnya sekolah ini hanya dibuka bagi warga Belanda di Hindia 
Belanda. Namun sejak 1903, kesempatan belajar juga diberikan kepada rakyat pribumi yang mampu dan warga Tionghoa. Selesai mengenyam pendidikan di ELS Europesche Lagere School, Soewardi meneruskan sekolah Kweekschool Sekolah Guru Belanda. Kemudian beliau pindah ke STOVIA yaitu Sekolah Dokter Bumi Putera dengan bantuan beasiswa dari keraton. Beliau sekolah di STOVIA selama 5 tahun, namun tidak sampai lulus dan terpaksa keluar karena sakit selama empat bulan dan membuatnya tidak naik kelas sehinga beasiswanya di cabut. Dibalik itu semua penyebab dikeluarkannya Soewardi dari Stovia lebih bersifat politis. Pencabutan beasiswa tersebut dilakukan sesaat setelah Soewardi mendeklamasikan sebuah sajak dalam sebuah pertemuan yang mana sajak itu menggambarkan keperwiraan Sentot Prawirodirdjo, panglima perang andalan Diponegoro. Sajak itu juga di terjemahkan dalam bahasa dalam bahasa Belanda yang sangat indah (Soewito, 1991: 10-12)

Ki Hadjar Dewantara meninggal dunia pada tanggal 26 Apri 1959, di rumahnya Mujamuju Yogyakarta. Tanggal 29 April, jenazah Ki Hadjar Dewantara dipindahkan ke pendopo Taman Siswa. Dari pendopo Taman Siswa, kemudian diserahkan kepada Majelis Luhur Taman Siswa. Dari pendopo Taman Siswa, jenazah diberangkatkan ke makan Wijaya Brata Yogyakarta. Dalam upacara pemakaman Ki Hadjar Dewantara dipimpin oleh Panglima Kodam Diponegoro Kolonel Soeharto Tanggal 28 November 1959, Ki Hadjar Dewantara ditetapkan sebagai "Pahlawan Nasional". Tanggal 16 Desember 1959, pemerintah menetapkan tanggal lahir Ki Hadjar Dewantara tanggal 2 Mei sebagai "Hari Pendidikan Nasional” berdasarkan keputusan Presiden RI Nomor: 316 tahun 1959 (Dewantara, 1962 : 137). Sebagai tokoh nasional yang dihormati dan disegani baik oleh kawan maupun lawan, Ki Hadjar Dewantara sangat kreatif, dinamis, jujur, sederhana, konsisten, konsekuen dan berani.

\section{Kilas Revolusi Industri 4.0}

Era industry 4.0 ditandai dengan memasuki era digitilasisasi di berbagai sektor kehidupan. Perubahan yang semula tersentralisasi pada manusia sebagai subyek elan vital dalam tumbuh dan berkembangnya denyut nadi perekonomian telah mengalami pergeseran secara perlahan dan tergantikan oleh otomatisasi mekanis dan digitalisasi teknologi dalam menggerakan roda perekonomian. 
Merujuk beberapa literatur Kamus Besar Bahasa Indonesia (KBBI) Revolusi industri terdiri dari dua kata yaitu revolusi dan industri. Revolusi berarti perubahan yang bersifat sangat cepat, sedangkan industri adalah usaha pelaksanaan proses produksi. Pengertian revolusi industri dapat disimpulka suatu perubahan yang berlangsung cepat dalam pelaksanaan proses produksi. Semula pekerjaan proses produksi itu dikerjakan oleh manusia yang untuk selanjutnya digantikan oleh mesin. Barang yang diproduksi pun mempunyai nilai tambah (value added) yang komersial. Dengan demikian pada konteks revolusi industri dapat diterjemahkan proses yang terjadi sebenarnya adalah perubahan sosial dan kebudayaan yang berlangsung secara cepat dan menyangkut dasar kebutuhan pokok (needs) dengan keinginan (wants) masyarakat.

Istilah revolusi industry diperkenalkan oleh Friedrich Engels dan Louis-Auguste Blanqui di pertengahan abad ke-19. Revolusi industri ini pun sedang berjalan dari masa ke masa. Dekade terakhir ini sudah dapat disebut memasuki fase ke empat 4.0. Perubahan fase ke fase memberi perbedaan artikulatif pada sisi kegunaaannya. Fase pertama (1.0) bertempuh pada penemuan mesin yang menitikberatkan (stressing) pada mekanisasi produksi. Fase kedua (2.0) sudah beranjak pada etape produksi massal yang terintegrasi dengan quality control dan standarisasi. Fase ketiga (3.0) memasuki tahapan keseragaman secara massal yang bertumpu pada integrasi komputerisasi. Fase keempat (4.0) telah menghadirkan digitalisasi dan otomatisasi perpaduan internet dengan manufaktur (Irianto, 2017).

Revolusi Industri 4.0 secara fundamental mengakibatkan berubahnya cara manusia berpikir, hidup, dan berhubungan satu dengan yang lain. Era ini akan mendisrupsi berbagai aktivitas manusia dalam berbagai bidang. Sektor ekonomi telah terlihat jasa transportasi dari kehadiran taksi dan ojek online. Hal yang sama juga terjadi di bidang sosial dan politik. Interaksi sosial pun menjadi tanpa batas (unlimited), melalui berbagai kemudahan sosial media. Kemdian aksi politik kini juga dapat dihimpun melalui gerakan-gerakan berbasis media sosial dengan mengusung ideologi politik tertentu.

Secara obyektif tidak dapat dipungkiri bahwa revolusi industri terkini menyimpan beragam keuntungan dan tantangan besar yang harus dihadapi bagi setiap entitas diri yang terlibat didalamnya. Salah satu keuntungan yang diperoleh adalah menemukan peluang baru 
namun juga diikuti oleh tantangan baru. Disisi lain, keadaan tersebut memunculkan kompetisi yang makin ketat. Kompetisi ini justru semakin meningkatkan kualitas internal maupun ekternal setiap individu (Suwardana, 2017). Kompetensi ini hendaknya dimulai penanaman mental produktif melalui lembaga pendidikan, sehingga tantangan revolusi industri 4.0 yang semakin berkompetensi dapat dihadapi. Penanaman mental produktif melalui pendidikan sebagaimana yang diungkapan sistem among KI Hajar Dewantara.

Industri 4.0 memberikan banyak manfaat, namun juga memiliki tantangan yang harus dihadapi. Drath dan Horch (2014) berpendapat bahwa tantangan yang dihadapi oleh suatu negara ketika menerapkan Industri 4.0 adalah munculnya resistansi terhadap perubahan demografi dan aspek sosial, ketidakstabilan kondisi politik, keterbatasan sumber daya, risiko bencana alam dan tuntutan penerapan teknologi yang ramah lingkungan. Di samping juga tak kalah pentingnya adalah aspek individu/manusia. Manusia secara individual harus mampu bersaing dan meningkatkan skill dalam berbagai aspek. Menurut Jian Qin dkk (2016), terdapat kesenjangan yang cukup lebar dari sisi teknologi antara kondisi dunia industri saat ini dengan kondisi yang diharapkan dari Industri 4.0. Penelitian

yang dilakukan oleh Balasingham (2016) juga menunjukkan adanya faktor keengganan perusahaan dalam menerapkan Industri 4.0 karena kuatir terhadap ketidak pastian manfaatnya.

Berdasar beberapa penjelasan tersebut maka sesuai dengan yang disampaikan oleh Zhou dkk (2015), secara umum ada lima tantangan besar yang akan dihadapi yaitu aspek pengetahuan, teknologi, ekonomi, sosial, dan politik. Guna menjawab tantangan tersebut diperlukan usaha yang besar, terencana dan strategis baik dari sisi regulator (pemerintah), kalangan akademisi maupun praktisi. Kagermann dkk (2013) menyampaikan diperlukan keterlibatan akademisi dalam bentuk penelitian dan pengembangan untuk mewujudkan Industri 4.0. Menurut Jian Qin dkk (2016) roadmap pengembangan teknologi untuk mewujudkan Industri 4.0 masih belum terarah. Hal ini terjadi karena Industri 4.0 masih berupa gagasan yang wujud nyata dari keseluruhan aspeknya belum jelas sehingga dapat memunculkan berbagai kemungkinan arah pengembangan.

\section{Konsep Pemikiran Pendidikan K.I Hajar Dewantara}


Pendidikan memegang peranan penting dalam memajukan suatu bangsa, sejak zaman perjuangan kemerdekaan dahulu, para pejuang serta perintis kemerdekaan telah menyadari bahwa pendidikan merupakan faktor yang sangat vital dalam usaha untuk mencerdaskan kehidupan bangsa serta membebaskannya dari belenggu penjajahan. Pendidikan dijadikan media untuk mengembangkan kemampuan dan membentuk watak serta peradaban bangsa yang bermartabat dalam rangka mencerdaskan kehidupan bangsa, bertujuan untuk mengembangkan potensi peserta didik.

Beberapa pemikiran pendidikan yang dikemukan KI Hajar Dewantara yakni, pertama tujuan pendidikan. Tujuan pendidikan yakni pendidikan sebagai tuntunan di dalam hidup tumbuhnya anak-anak, artinya pendidikan menuntun segala kekuatan kodrat yang ada pada anak-anak itu, agar mereka sebagai manusia dan sebagai anggota merdeka baik secara fisik, mental, dan kerohanian. Kemerdekaan pribadi dibatasi oleh tertib damai kehidupan bersama, dan ini mendukung sikap-sikap seperti keselarasan, kekeluargaan, musyawarah, toleransi, kebersamaan, demokrasi, tanggungjawab, dan disiplin (Mujito, 2014 : 70)Manusia merdeka adalah seseorang yang mampu berkembang secara utuh dan selaras dari segala aspek kemanusiaanya dan yang mampu menghargai dan menghormati kemanusiaan setiap orang (Widyastono, $2014: 131$ )

Kedua bagi pendidik Ki Hadjar Dewantara memberikan beberapa pedoman dalam menciptakan kultur positif seorang pendidik, yang dingkapkan Tut wuri handayani, dari belakang seorang guru harus bisa memberikan dorongan dan arahan. Ing madya mangun karsa pada saat di antara pesetra didik, guru harus menciptakan prakarsa dan ide. Ing ngarsa sung tulada, berarti ketika guru berada di depan, seorang guru harus memberi teladan atau contoh dengan tindakan yang baik (Mujito, 2014 : 69). Istilah ini merupakan kompetensi pedagodik yang dimiliki pendidik. Pendidik memahami peserta didik, pengalaman, kemampuan, dan prestasinya. Menggunakan metode dan media yang bervariasi dalam mengajar dan membentuk kompetensi peserta didik. Selanjutnya pendidik bagi Ki. Hajar dewantara terdiri dari orang tua, guru atau pemimpin, termasuk pemimpin spiritual, peran pendidik yaitu sebagai fasilitator dan motivator (Yanuarti, 2017 : 250). Bagi Ki Hajar Dewantara, para guru hendaknya menjadi pribadi yang bermutu dalam kepribadian dan kerohanian, baru kemudian menyediakan diri untuk menjadi pahlawan dan juga menyiapkan 
para peserta didik untuk menjadi pembela nusa dan bangsa. Dengan kata lain, yang diutamakan sebagai pendidik pertama-tama adalah fungsinya sebagai model atau figure keteladanan, baru kemudian sebagai fasilitator atau pengajar.

Ketiga bagi peserta didik handaklah memiliki prinsip kemerdekaan pada individu. Bagi KI Hajar Dewantara Kemerdekaan atau kemampuan pribadi bertujuan agar peserta didik dapat leluasa mengembangkan cipta, rasa, dan karsa dalam proses belajar. Hal ini selaras dengan semboyan "Tutwuri Handayani". Yang berarti mengikuti dari belakang dan memberikan pengaruh. Mengikuti dari belakang berarti memberikan kebebasan kepada anak didik tanpa meninggalkan pengawasan. Sehingga anak didik tidak bebas lepas tanpa pengawasan dan juga tidak terkekang atau terhambat dalam pertumbuhan dan perkembangannya sebagai manusia merdeka (Dewantara, 2017 :4). Selanjutnya Peserta didik tidak melalaikan kewajibanya baik kewajiban terhadap Tuhan, Lingkungan, masyarakat, maupun diri sendiri. Ki Hajar Dewantara melaksanakan pendidikan budi pekerti dengan cara tutu wuri handayani, yang dikenal dengan sistem Among. Among berarti asuhan dan pemeliharaan dengan suka duka dengan memberi kebebasan anak asuhan bergerak menurut kemauannya (Tauchid, 1963 :36). Artinya peserta didik harus mampu membangun skill agar berdaya guna. Hal ini pula bagi KI hajar dewantara bahwa peserta didik harus mampu mengembangkan daya cipta rasa dan karsa yang seimbang.

Menurut KI Hajar Dewanatara manusia memiliki daya jiwa yaitu cipta, karsa dan karya. Pengembangan manusia seutuhnya menuntut pengembangan semua daya secara seimbang. Ternyata pendidikan sampai sekarang ini hanya menekankan pada pengembangan daya cipta, dan kurang memperhatikan pengembangan olah rasa dan karsa. Jika berlanjut terus akan menjadikan manusia kurang humanis atau manusiawi. Sedangkan bagi Ki Hajar Dewantara

Pemikiran Ki Hadjar Dewantara direalisasikan secara nyata dengan menerapkan secara langsung di perguruan Taman Siswa yang didirikannya sebagai pembuktian bahwa pemikiran dan tujuan yang ingin dicapainya tersampaikan dengan baik sesuai harapannya semata-mata untuk mencerdaskan kehidupan bangsa. Adapun asas-asas pendidikan yang dirancangnya tertuang sebagai asas taman siswa sebagai berikut (Acetyena, :35-37) 
a. Asas Kebangsaan, taman Siswa tidak boleh bertentangan dengan kemanusiaan, akan tetapi, harus menjadi bentuk kemanusiaan yang nyata dan oleh karena itu tidak mengandung arti permusuhan dengan bangsa lain, melainkan mengandung rasa dan duka, rasa dalam kehendak menuju kepada kebahagiaan hidup lahir dan bathin seluruh bangsa.

b. Asas Kebudayaan, Taman Siswa tidak berarti asal memelihara kebudayaan kebangsaan. akan tetapi, pertama-tama membawa kebudayaan kebangsaan itu menuju ke arah kemajuan yang sesuai dengan kecerdasan bangsa disetiap zamannya, kemajuan dunia, dan kepentingan hidup rakyat lahir dan bathin pada tiap-tiap zaman dan keadaan.

c. Asas Kemerdekaan berarti disiplin pada diri sendiri dan oleh diri sendiri atas dasar nilai hidup yang tinggi, baik hidup sebagai individu maupun anggota masyarakat. Maka, kemerdekaan itu harus menjadi alat pengembangan kepribadian yang kuat. Artinya, pendidikan bertujuan untuk menjadikan anak menjadi seseorang yang disiplin terhadap diri sendiri dalam segala hal untuk dapat membangun kepribadian anak sehingga membuatnya tidak menjadi sewenang-wenangnya dalam berbuat.

d. Asas kemanusiaan menyatakan bahwa dharma tiap-tiap manusia mewujudkan kemanusiaan, yang berarti kemajuan manusia lahir dan bathin yang setinggi-tingginya, kemajuan kemanusiaan yang tinggi dapat dilihat pada kesucian hati seseorang dan adanya rasa cinta kasih terhadap sesama manusia dan terhadap segala makhluk ciptaan Tuhan. Yaitu yang bersifat keyakinan adanya hukum kemajuan yang meliputi alam semesta. Artinya tujuan pendidikan yang dimaksudkan oleh Ki Hadjar Dewantara agar dapat menghasilkan anak-anak yang memiliki jiwa sosial yang tinggi sehingga dapat berguna bagi nusa dan bangsa.

e. Asas Kodrat Alam berarti bahwa pada hakikatnya manusia itu sebagai makhluk adalah satu dengan kodrat alam ini. Ia tidak bisa lepas dari kehendaknya, akan tetapi merupakan suatu kebahagiaan apabila manusia bisa menyatukan diri dengan kodrat alam yang memiliki dampak kemajuan. Artinya, bahwa manusia terlahir dengan kodrat dan bakat sejak lahir yang tak bisa dipungkiri, bakat dan dan bawaan sejak lahir apabila terus di asah akan menjadi sesuatu yang berharga untuknya dimasa depan akan tetapi hal tersebut tentunya harus disesuaikan dengan keadaan.

\section{Pendidikan Sistem Among K.I Hajar Dewantara dalam Era Revolusi Industri 4.0}


Lahirnya sistem among sangat berkaitan dengan keadaan pendidikan yang dipengaruhi oleh sistem barat. Dalam sistem barat, dasar-dasarnya adalah regering, tucht dan orde (perintah, hukuman dan ketertiban). Ki Hadjar Dewantara menilai pendidikan seperti itu dapat menyebabkan rusaknya budi pekerti anak, sebab anak mengalami pemerkosaan terhadap kehidupan batinnya. Sistem tersebut juga menyebabkan anak selalu hidup berada di bawah paksaan dan hukuman yang tidak setimpal dengan kesalahannya. Ki Hadjar Dewantara tidak setuju dengan sistem pendidikan yang membangun watak anak dengan sengaja, dengan cara perintah, paksaan terhadap batin anak, paksaan untuk tertib dan paksaan untuk sopan. Ki Hadjar Dewantara menilai bahwa jika meniru cara yang demikian maka tidak akan dapat membentuk seseorang yang memiliki kepribadian (I Putu Ayub Darmawan, 2016 : 126)

Atas dasar inilah sistem pendidikan yang dikedepankan KI Hajar Dewantara yakni cara opvoeding atau pedagogik (momong, among, dan ngemong). Cara yang dipakainya adalah orde en vrede tertib dan damai, tata-tentram, namun tidak melakukan pembiaran. (Tauchid dkk.,1962:13). Menurut KI Hajar Dewantara pendidikan harus menjunjung tinggi suka cita dan membuka kekuatan pikiran dan watak anak, itu sebabnya ia mengedepankan pendidikan dengan sistem among (Dewantara, 1957: 21-23).

Kata Momong dalam bahasa Jawa berarti merawat dengan penuh ketulusan dan penuh kasih sayang serta mentransformasikan kebiasaan-kebiasaan atau membiasakan melakukan hal-hal yang baik disertai dengan do'a dan harapan. Hasil didikan dan kasih sayangnya membuat anak menjadi anak yang baik dan senantiasa berada pada jalan kebenaran. Among dalam bahasa jawa berarti memberikan contoh tentang baik buruk tanpa harus mengambil hak anak agar bisa tumbuh dan berkembang dalam suasana bathin yang merdeka sesuai dengan dasarnya. Ngemong dalam bahasa Jawa berarti proses untuk mengamati, merawat, dan menjaga agar anak mampu mengembangkan dirinya, bertanggung jawab dan disiplin berdasarkan nilai-nilai yang telah diperoleh sesuai dengan kodratnya (Rahardjo, $2018: 71$ ).

Uraian di atas memberikan makna sistem among atau mengemong adalah memberikan kebebasan kepada anak untuk dapat melakukan pergerakan menurut kemauannya sendiri, tetapi tetap berada dalam pengawasan seorang guru yang berperan 
sebagai pamong. Sistem among Ki Hadjar Dewantara adalah memberikan kebebasan kepada siswa untuk belajar mengenai sesuatu yang baik berdasarkan pengalamannya sendiri. Namun berada dalam pengawasan guru. Bagi KI Hajar Dewantara sebagai pendidik pertama-tama fungsinya adalah sebagai model atau figure keteladanan, baru kemudian sebagai fasilitator atau pengajar. Oleh karena itu, KI Hajar memaknai sebagai guru yang mengajarkan kebaikan, keluhuran, keutamaan. Ki Hadjar Dewantara mengibaratkan sistem among dengan gambaran bahwa guru harus berfikir, berperasaan, dan bersikap. Bagi Ki Hadjar Dewantara guru memiliki peranan penting dalam mendidik anak sehingga memiliki kualitas terbaik yang diharapkan.

Hal ini juga digambarkan K.I Hajar Dewantara dalam semboyan Ing Ngarsa Sung Tulada, berarti ketika pendidik berada di depan, seorang guru harus memberi teladan atau contoh dengan tindakan yang baik, kemudian pendidik membangun suatu etos kerja yang positif yaitu menjunjung tinggi pekerjaan; menjaga harga diri dalam melaksanakan pekerjaan, dan keinginan untuk melayani masyarakat. Tut Wuri Handayani, dari belakang seorang pendidik harus dapat memberikan dorongan dan arahan. Kemudian, Ing Madya Mangun Karsa pada saat di antara peserta didik, pendidik harus menciptakan prakarsa dan ide (Eka Yanuartu, 2017 : 251).

Selanjutnya manusia merdeka merupakan tujuan pendidikan Ki Hadjar Dewantara. Merdeka baik secara fisik, mental, dan kerohanian. Kemerdekaan pribadi dibatasi oleh tertib damai kehidupan bersama, dan ini mendukung sikap-sikap seperti keselarasan, kekeluargaan, musyawarah, toleransi, kebersamaan, demokrasi, tanggungjawab, dan disiplin (Dewantara, 2009 : 15) Manusia merdeka adalah seseorang yang mampu berkembang secara utuh dan selaras dari segala aspek kemanusiaanya dan yang mampu menghargai dan menghormati kemanusiaan setiap orang (Suparto Raharadjo, 2018 :85)

Berbagai pemikiran pendidikan menurut KI. Hajar Dewantara di atas dapat disebut dalam kosep pendidikan sistem pamong. Sistem pendidikan ini adalah sistem among yaitu metode pengajaran dan pendidikan yang berdasarkan pada asih, asah dan asuh (care and dedication based on love). Dalam sistem among siswa bebas berkreatifitas serta diberikan kebebasan untuk memberikan pandangan sendiri terhadap suatu hal atas dasar pengalamannya sendiri.

395 | Seminar Nasional Sejarah ke 4 Jurusan Pendidikan Sejarah Universitas Negeri Padang 
Sistem among sebenarnya berdasarkan cara berlakunya tidak lepas dari semboyan Tut Wuri Handayani. Di dalam sistem tersebut pelaksanaan pendidikan lebih didasarkan pada minat dan potensi yang perlu dikembangkan pada anak didik, bukan pada minat dan keamampuan yang dimiliki oleh pendidik. Apabila pengembangan potensi anak berada pada jalan yang salah maka pendidik berhak untuk meluruskannya.

Menurut Ki Hadjar Dewantara syarat untuk membimbing anak-anak untuk menjadi orang yang sungguh-sungguh merdeka lahir maupun bathin adalah dengan cara memerdekakan bathin, pikiran dan tenaga anak. Akan tetapi, tidak boleh terlalu mengutamakan kecerdasan anak sehingga mengesampingkan dalam hal mengimbangi perasaannya. Baginya pikiran dan perasaan anak haruslah diseimbangkan dan saling menunjang. Oleh karena itu metode asah asih dan asuh dalam sistem among merupakan hal yang tepat dikembangkan pada anak didik. Dalam istilah lain sistem among K.I Hajar dewantara adalah pada paserta didik hendaklah mengembangkan daya cipta, rasa dan karsa.

Daya cipta rasa dan karsa merupakan istilah yang sering didengar dan tidak asing, bahkan founding father Soekarno pernah mengugkapkan bahwa sebagai manusia Indonesia seutuhnya dlaam berkehidupan haruslah selaras serasi dan seimbang antra cipta rasa dan karsa. Hal ini pulala yang diungkapkan oleh KI hajar dewantara dalam konsep pendidikan. Bahwa cipta rasa dan karsa istilah sedernaha namun perlu dipahami hakekat makna yang terkandung di dalamnya. Sebab bicara cipta rasa dan karsa juga terkait dengan esensi manusi sesungguhnya dalam penerapannya kehidupan sehari-hari. Terutama terkait dalam perkembangan revolusi industry 4.0. Bahwa perkembangan teknologi telah mencapai tahap revolusi industri 4.0, maka pendidikan sistem among yang dikonsepkan dalam istilah cipta rasa dan karsa sangatlah tepat di terapkan.

Perkembangan industri 4.0 pada dasarnya memberikan dampak. Hasil penelitian dari McKinsey pada 2016 bahwa dampak dari digital tecnology menuju revolusi industri 4.0 bahwa kedepan akan ada 52,6 juta jenis pekerjaan akan mengalami pergeseran atau hilang dari muka bumi Hendra 103. Hasil penelitian ini memberikan pesan bahwa setiap diri yang masih ingin mempunyai eksistensi diri dalam kompetisi global harus mempersiapkan mental dan skill yang mempunyai keunggulan persaingan (competitive advantage) dari lainnya (Hendra Suwardana, 2017 : 103).

396 | Seminar Nasional Sejarah ke 4 Jurusan Pendidikan Sejarah Universitas Negeri Padang 
Jalan utama mempersiapkan skill yang mesti mudah ditempuh adalah bekal persiapan diri yang dapat dilalui dengan jalur pendidikan (long life education). Melalui pendidikan kunci keberhasilan memasuki revolusi industri 4.0. Melalui pendidikan pula dapat membentuk karakter bangsa. Lembaga pendidikan harus mampu menjawab tantangan tersebut untuk menghgasilkan manusia yang unggul melalui penanaman cipta raasa dan karsa.

Sejalan dengan itu cipta rasa dan karsa dalam istilah sekarang dapat disebut sebagai revolusi mental. Revolusi mental adalah gerakan bersama menyadarkan diri betapa pentingnya meningkatkan kompetensi diri melalui pendidikan dan meningkatkan potensi diri melalui pelatihan. Menurut Prof Ermaya (2015) revolusi mental pada hakikatnya mengisi mental manusia dengan nilai luhur (nilai agama, nilai tradisi budaya dan nilai falsafah bangsa) secara besar-besaran sehingga terbentuk skill dan kemampuan seta karakter baik. Secara subtansi paradigma revolusi mental adalah pandangan baru tentang perubahan besar dalam struktur mental manusia dalam membangun mentalitas skill baik manusia.

Sebagai revolus digital, pada tahap ini, dunia memperoleh internet dengan interkonektivitas yang begitu cepat. Tak terpikir sebelumnya bahwa kita bisa menjelejahi dunia maya dengan menggunakan komputer. Oleh karena itu, melalui pendidikan dengan penerapan sistem among KI hajar dewantara hendaklah dapat membangun mansuia yang unggul. Melalui peningkatan kemmapuan berfikir dan bernalar disertai dengan mersasakan dan kemauan kuat. Cipta merupakan hasil dari proses pikiran atau akal, sedangkan rasa bertumpu kepada perasaan, dan karsa adalah niat atau kemauan yang kuat dari seseorang. Hasil dari cipta rasa dan karsa adalah adalah terdapatnya karya, jadi karya adalah bentuk tindakan nyata setelah proses cipta dan rasa. Terkait industry 4.0 dalam bidang pendidikan pada peserta didik hari ini hendaklah mengembangan tingkat daya cipta dan rasa sebagaimana yang diungkapkan oleh K.I Hjara Dewantara.

Revolusi industri 4.0 berjalan dengan dilandasi daya cipta rasa dan karsa. Paradigma ini akan adanya perubahan besar dan terbangun tiga hal yaitu cara berpikir, meyakini dan cara bersikap. Pendidkan sistem among dengan emmabngun daya cipta rasa dan karsa akan membangun potensi peningkatan potensi diri guna menyikapi era globalisasi yang berwatak revolusi industri 4.0. Pada era ini diperlukan literasi baru dengan menggunakan analisa data 
secara menyeluruh serta membuat konklusi agar terkait dengan kemampuan komunikasi, kolaborasi, berpikir kritis, kreatif dan inovatif.

Berdasarkan inilah diperlukan mahasiswa dengan daya cipta rasa dan karsa membangun kemampuan berfikir kritis dan analitis, serta membangun komunikasi dan kreatif. Melaui ini sistem diskusi dikelas dalam pemanfaatn teknologi khususnya Hanphone, tidak hanya sebatas pencaharian materi dan menyampaikan materi dengan tekstual. Melalui sismtem among dapat emningkatkan karya manusia.

\section{Simpulan}

Pendidikan sistem among merupakan metode pengajaran dan pendidikan yang berdasarkan pada asih, asah dan asuh. Sistem among sebenarnya berdasarkan cara berlakunya tidak lepas dari semboyan Tut Wuri Handayani. Di dalam sistem tersebut pelaksanaan pendidikan lebih didasarkan pada minat dan potensi yang perlu dikembangkan pada anak didik, namun peran pendidik memberikan pengawasan terhadap peserta didik. Dalam sistem among siswa bebas berkreatifitas serta diberikan kebebasan untuk memberikan pandangan sendiri terhadap suatu hal atas dasar pengalamannya sendiri. Menurut Ki Hadjar Dewantara anak-anak didik harus menjadi manusia merdeka. dengan cara memerdekakan bathin, pikiran dan tenaga anak. Akan tetapi, tidak boleh terlalu mengutamakan kecerdasan anak sehingga mengesampingkan dalam hal mengimbangi perasaannya. Baginya pikiran dan perasaan anak haruslah diseimbangkan dan saling menunjang. Sehingga adanya keseimbangancipta rasa dan karsa dalam peserta didik

Terkiat revolusi industry 4.0 tentu saja memberikan tantangan tersendiri pada generasi muda hari ini. Untuk menjawab tantangan tersebut diperlukan usaha yang besar, terencana dan strategis baik dari sisi regulator/ pemerintah, praktisi, maupun kalangan akademik. Dalam menghadapi revolusi industri 4.0, maka penulis berpendapat terdapat dua jalan yang meski ditempuh. Pertama, menyiapkan pelaksanaan pendidikan yang link and match antara sumber daya manusia dan kebutuhan zaman di era revolusi industri. Pelaksanaan pendidikan melahirkan

manusia yang memilki daya cipta rasa dan karsa. Kedua, selain menyiapkan pendidikan yang link and match, sumber daya manusia yang disiapkan juga harus dibekali dengan pendidikan 
nilai-nilai kemanusiaan sebagaimana yang terdapat dalam pendidikan sistem among KI hajar Dewantara.

Sintesis revolusi industri 4.0 akan melahirkan masyarakat sejahtera dalam pembangunan, sedangkan pendidikan yang mengasah skill akan melahirkan manusia yang berkualitas dan unggul. Disinilah urgensinya sinergisitas revolusi industri 4.0 sebagai kebutuhan dengan pendidikan sistem among yang menekankan aspek pemberdayaan manusia atau pserta didik.

\section{DAFTAR PUSTAKA}

Afnil. Guza, 2009. Undang-Undang Sistem Pendidikan Nasional dan Undang-Udang Guru dan Dosen. Jakarta : Asa Mandiri.

Banu Prasetyo. Tth. "Revolusi Industri 4.0 Dan Tantangan Perubahan Sosial”, Artikel.

Drajad Irianto, 2017. BKSTI ub.ac.id /wp-content/upload/2017/10/keynote Speker Drajad Irianto.pdf

Darsiti Soeratman. 1989. Ki Hadjar Dewantara. Jakarta: Proyek Inventaris dan Dokumentasi Sejarah

Drath, R., \& Horch, A. (2014). "Industrie 4.0: Hit or hype?(industry forum)". IEEE industrial electronics magazine, 8(2), pp. 56-58

Eka Yanuarti, 2007"Pemikiran pendidikan ki. Hajar dewantara dan relevansinya dengan kurikulum 13", Jurnal Penelitian, Vol. 2. No. Agustus.

Hadi Soewito, 1991. Soewardi Soerjaningrat dalam Pengasingan. Jakarta: Balai Pustaka

Hendra Suwardana. 2017. "Revolusi Industri 4.0 Berbasis Revolusi Mental”. Jurnal Jati Unik. Vol.1. No.2.

Heri Widyastono, 2014. Pengembangan Kurikulum di Era Otonomi Daerah dari Kurikulum 2004, 2006, ke Kurikulum 2013, Jakarta: Bumi Aksara.

J. Qin, Y.Liu, \& R.Grosvenor, (2016). A Categorical Framework of Manufacturing for Industry 4.0 and Beyond. Procedia CIRP, Vol. 52, pp. 173-178.

I Putu Ayub Darmawan, 2016. "Pandangan dan Konsep Pendidikan Ki Hadjar Dewantara", Artikel

Kagermann, H., Lukas, W.D., \& Wahlster, W. (2013). Final report: Recommendations for implementing the strategic initiative Industrie 4.0. Industrie 4.0 Working Group. 
Ki Hadjar Dewantara,. 1957. Masalah Kebudajaan. Jogjakarta: Madjelis Luhur Persatuan Taman Siswa

Ki Hadjar Dewantara, 2009 Menuju Manusia Merdeka. Yogyakarta: Leutika

Ki Hadjar Dewantara, 1962. Karya Bagian I: Pendidikan. cet II.Yogyakarta: MLPTS.

le Febre, W. 1952.Taman Siswa. Djakarta \& Surabaja: Penerbitan dan Balai Buku Indonesia

Moch Tauchid, 1967. "Tugas Taman Siswa dalam Pembangunan Masyarakat Baru.” Pusara 67, Djilid XXVIII, No. 7-8

Rusniati. Jurnal Didaktika. vol. 16, no I, 105-128

Sita Acetylena, 2018. Pendidikan Karakter Ki Hadjar Dewantara. Malang: Madani

Suparto Rahardjo. 2018. Ki Hajar Dewantara Biografi Singkat 1889-1559.Jogjakarta: Garasi

Wawan Eko Mujito, "Konsep Belajar Menurut Ki Hadjar Dewantara dan Relevansinya dengan Pendidikan Agama Islam”, Jurnal Pendidikan Agama Islam, Vol. XI, No. 1, Juni 2014. 